\title{
Fly Ash for Removal of Contaminates from Coal Mine Drainage
}

\author{
Shadi Abu-Baker*, Shahrokh Ghaffari*, Lucy Egdell, Kristin Haser \\ College of Arts and Sciences, Ohio University Zanesville, Zanesville, USA \\ Email: *abu@ohio.edu, *ghaffari@ohio.edu
}

How to cite this paper: Abu-Baker, S., Ghaffari, S., Egdell, L. and Haser, K. (2016) Fly Ash for Removal of Contaminates from Coal Mine Drainage. Natural Science, 8, 397-402.

http://dx.doi.org/10.4236/ns.2016.89043

Received: March 23, 2016

Accepted: September 5, 2016

Published: September 8, 2016

Copyright $\odot 2016$ by authors and Scientific Research Publishing Inc. This work is licensed under the Creative Commons Attribution International License (CC BY 4.0). http://creativecommons.org/licenses/by/4.0/ (c) (i) Open Access

\begin{abstract}
In this study, fly ash obtained from a coal burning power plant was used to remove iron from coal mine drainage as well as raising the $\mathrm{pH}$ to acceptable limits for natural water using column chromatography. The results of this study indicate that fly ash has the ability to completely remove iron and reduce acidity of coal mine water drainage. This approach can be extended to include other contaminants such as magnesium.
\end{abstract}

\section{Keywords}

Fly Ash, Coal Mine, Water Contamination Reduction, Iron Contamination

\section{Introduction}

Finding a cost-effective and efficient method to remove hazardous substances from water is a challenge that many local communities is facing in the USA and elsewhere. Investigating innovative technologies to accomplish this goal will benefit not only our local environments but also the global habitat. This study will probe the capability and capacity of fly ash to remove environmentally unfriendly substances.

Acid Mine Drainage (AMD) from abandoned coal mines is the primary source of water pollution in the Appalachian community in Ohio. Approximately 340 miles of Southeast Ohio streams are affected by AMD. Most of those streams suffer from elevated concentrations of metals like iron, aluminum and manganese [1]. According to the "Appalachian Regional Commission 1973," the EPA cites Acid drainage problems that exist in Pennsylvania, West Virginia, Ohio, Kentucky, Maryland, Indiana, Illinois, Oklahoma, Iowa, Missouri, Kansas, Tennessee, Virginia, Alabama, and Georgia [2]. Therefore, the environmental impact caused by this kind of pollution is extensive. According to division of mineral resources management of Ohio Department of Natural 
Resources there are 1300 miles of streams impacted by acid mine drainage [3].

The Acid Mine Drainage (AMD) is polluted water that normally contains sulfuric acid and high levels of metals such as iron, magnesium, and aluminum [4]. There are many types of sulfide minerals, but iron sulfides such as pyrite and marcasite $\left(\mathrm{FeS}_{2}\right)$ that are common in coal regions are the predominant AMD producers. Upon exposure to water and oxygen, pyritic minerals oxidize to form acidic, iron and sulfate-rich drainage.

The following series of reactions are the cause of the AMD [5]:

$$
\begin{gathered}
2 \mathrm{FeS}_{2}+7 \mathrm{O}_{2}+2 \mathrm{H}_{2} \mathrm{O} \rightarrow 2 \mathrm{Fe}^{2+}+4 \mathrm{SO}_{4}^{2-}+4 \mathrm{H}^{+} \\
\mathrm{FeS}_{2}+14 \mathrm{Fe}^{3+}+8 \mathrm{H}_{2} \mathrm{O} \rightarrow 15 \mathrm{FeS}^{2+}+2 \mathrm{SO}_{4}^{2-}+16 \mathrm{H}^{+} \\
4 \mathrm{Fe}^{2+}+\mathrm{O}_{2}+4 \mathrm{H}^{+} \rightarrow 4 \mathrm{Fe}^{3+}+2 \mathrm{H}_{2} \mathrm{O}
\end{gathered}
$$

Some bacteria present in mines act as a catalyst in generating AMD, resulting in formation of ferric hydroxide precipitates "yellow boy".

$$
\mathrm{Fe}^{3+}+3 \mathrm{H}_{2} \mathrm{O} \rightarrow \mathrm{Fe}(\mathrm{OH})_{3}+3 \mathrm{H}^{+}
$$

Fly Ash is a coal combustion product (CCP) resulting from the process of burning coal to produce electricity. According to the American Coal Ash Association, nearly $75 \%$ of fly ash produced in the United States is disposed in landfills. In Ohio that percentage is $80 \%$ [5]. Preliminary data indicate that fly ash has the potential to trap organic matter, odor-causing matter, and colored materials. Fly ash also shows promise as a soil stabilizer and erosion blocker [6]. Fly ash which contains $\mathrm{Ca}(\mathrm{OH})_{2}$ and $\mathrm{CaCO}_{3}$ has ability to neutralize acid. Neutralization value varies with each product.

The main objective of this project is to perform the necessary fundamental study on the ability of fly ash to absorb certain substances such as iron and magnesium from acid mine drainage as well as to adjust the $\mathrm{pH}$ in the hopes of developing additional re-use technologies for this byproduct. The federally required water $\mathrm{pH}$ level is $6.5-9.0$ and most acid mine drainages are below 4 . The same situation holds for iron where the federally required level is $3.0 \mathrm{mg} / \mathrm{L}$ while acid mine drainages contain more than $30-60$ times that.

The previous undergraduate research work at OUZ indicates that fly ash has the ability to remove environmentally hazardous materials such as fuel [7] and hydrogen sulfide (unpublished paper) from water.

\section{Methods}

The first stage of this project was to locate a site for collecting samples. Acid mine drainage is known to be a major problem within old coal mining environments. Initially, different locations were considered. Finally, the site selected for this project was based on two factors, a short distance from OUZ campus and accessibility for sampling (Figure 1).

The $\mathrm{pH}$ and temperature of each sample was measured at the sampling site. Samples that were properly collected were brought to the research lab to be analyzed for iron 


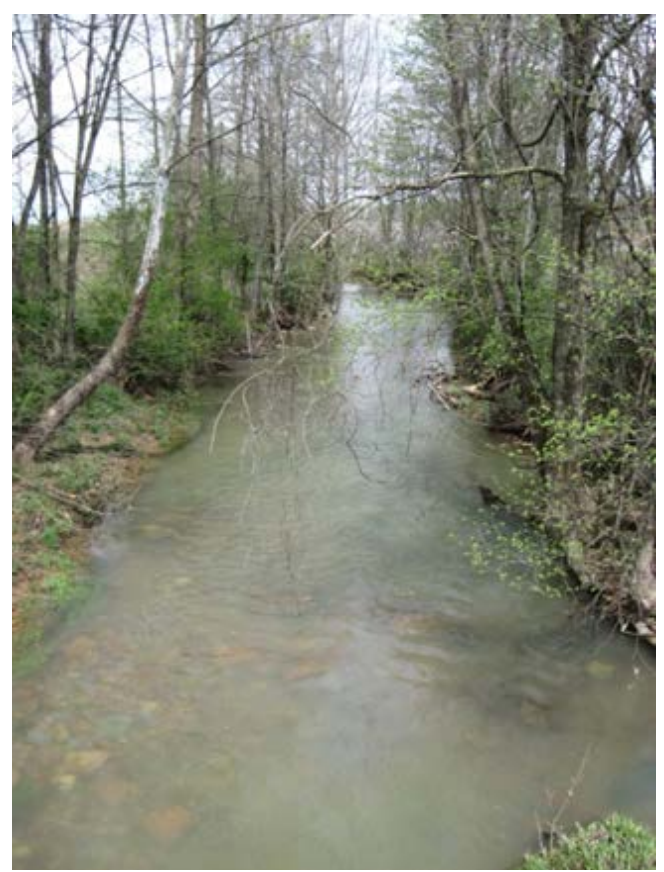

Figure 1. The site for collecting samples was the buckeye creek.

and other metal contents as well as acidity level. The analysis of the samples then required separation of contaminates by column chromatography using fly ash as the packing material (Figure 2).

Five columns $(11 \times 30 \mathrm{~mm}$ glass $)$ were packed with $2,4,6,8$, and 10 grams of fly ash. Then each column was washed three times with $100 \mathrm{~mL}$ portions of deionized water to remove any component of fly ash that may be eluted from columns during the experiment. The third washing was used as a reference (blank). A calibration curve was produced using standard solutions of known substance of interest namely iron. When the columns were ready a $10 \mathrm{~mL}$ sample of contaminated acid mine were run through each column and eluted samples were collected for further analysis for metal content and acidity (Figure 3). Concentration of iron and magnesium were measured before and after elution by the following spectrophotometric method for trace amount of iron using Spectronic Genesys 5 spectrophotometer with photometric accuracy of $0.003 \mathrm{~A}$.

To be able to detect iron using this method, samples must be colored. Iron will form an intensely red-orange colored complex with 1,10-phenanthroline (phen) in the $\mathrm{pH}$ range of $3-9$.

$$
\mathrm{Fe}^{2+}+3 \text { phen } \rightarrow \mathrm{Fe}(\text { phen })_{3}^{2+}
$$

The most common state of iron in the water is $\mathrm{Fe}^{3+}$. Therefore, it is necessary to first reduce $\mathrm{Fe}^{3+}$ to $\mathrm{Fe}^{2+}$. This is accomplished by the addition of hydroxylamine. To have stable $\mathrm{pH}$, sodium acetate was used as a buffer to maintain a constant $\mathrm{pH}$ at 3.5 [8].

Iron-phen complex has maximum absorbance at $512 \mathrm{~nm}$ wavelength. All measurements using spectrophometer were done at this wavelength. The amount of magnesium in samples was measured using standard EDTA method as described in literature [8]. 


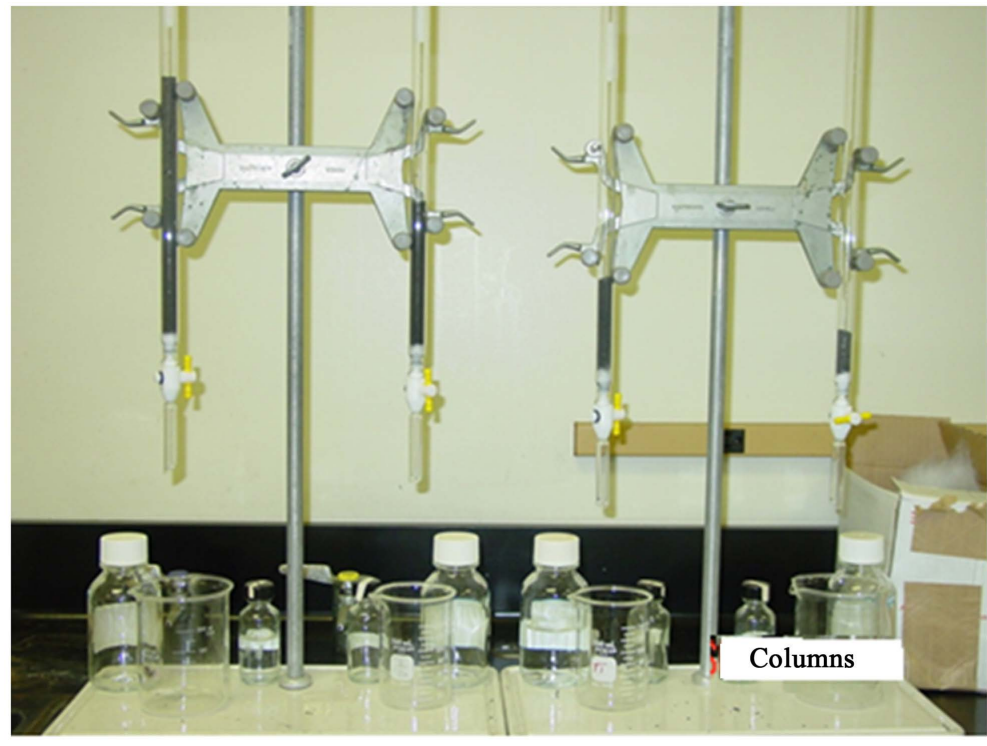

Figure 2. Separation of contaminates by column chromatography set-up.

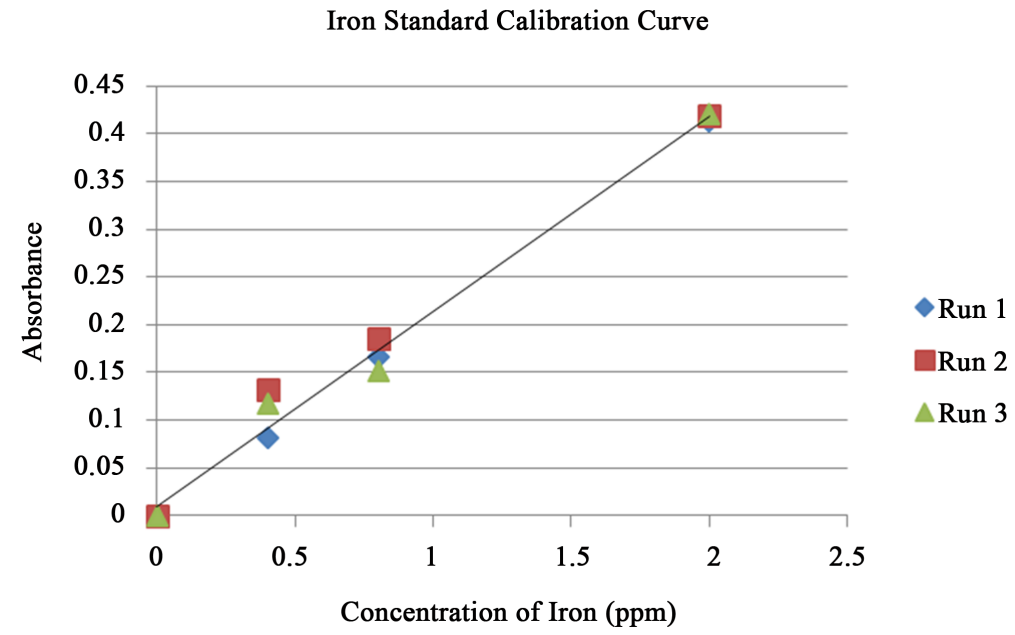

Figure 3. Calibration curve for iron.

\section{Results and Discussion}

At the time of the first sample collection, we noticed unusually high water level due to rain in the creek. Therefore, the initial concentrations were lower than the expected normal level around the year. Table 1 represents the result of first treatment of AMD water. The results show that the more fly ash was used, the more efficient iron removal from our $10 \mathrm{~mL}$ of sample was achieved.

The second samples were collected one month later when the water levels were leass and about normal. As indicated in Table 2 the concentration of iron is higher and treated AMD water does not contain any detectable trace of iron.

This method can be extended to purify water from other ion contaminants such as magnesium. Our preliminary measurement using $10 \mathrm{~g}$ fly ash showed a 20 fold reduction 
Table 1. Concentration of iron before and after treatment.

\begin{tabular}{ccccc}
\hline \multirow{2}{*}{$\begin{array}{c}\text { Mass of Fly } \\
\text { Ash (grams) }\end{array}$} & Before treatment & $\begin{array}{c}\text { After Treatment } \\
\text { Run 1 }\end{array}$ & $\begin{array}{c}\text { After treatment } \\
\text { Run 2 }\end{array}$ & Average of 2 runs \\
\cline { 2 - 5 } & 0.064 & 0.017 & 0.017 & $0.017 \pm 0.000$ \\
2 & 0.064 & 0.012 & 0.015 & $0.014 \pm 0.002$ \\
6 & 0.064 & 0.014 & 0.009 & $0.012 \pm 0.004$ \\
8 & 0.064 & 0.003 & 0.000 & $0.000 \pm 0.001$ \\
10 & 0.064 & 0.000 & 0.000 & $0.000 \pm 0.000$ \\
\hline
\end{tabular}

Table 2. Concentration of iron before and after treatment.

\begin{tabular}{ccccc}
\hline \multirow{2}{*}{$\begin{array}{c}\text { Mass of Fly } \\
\text { Ash (grams) }\end{array}$} & Before treatment & $\begin{array}{c}\text { After Treatment } \\
\text { Run 1 }\end{array}$ & $\begin{array}{c}\text { After treatment } \\
\text { Run 2 }\end{array}$ & Average of 2 runs \\
\cline { 2 - 4 } & 0.085 & 0.000 & 0.000 & $0.000 \pm 0.000$ \\
4 & 0.085 & 0.000 & 0.000 & $0.000 \pm 0.000$ \\
10 & 0.085 & 0.000 & 0.000 & $0.000 \pm 0.000$ \\
\hline
\end{tabular}

Table 3. $\mathrm{pH}$ measurement before and after treatment.

\begin{tabular}{ccc}
\hline \multirow{2}{*}{ Mass of Fly Ash (grams) } & \multicolumn{2}{c}{ Sample 1 pH measurement } \\
\cline { 2 - 3 } & Before treatment & After Treatment Run 1 \\
\hline 4 & 4.88 & 7.82 \\
6 & 4.88 & 8.15 \\
8 & 4.88 & 8.15 \\
10 & 4.88 & 8.06 \\
\hline
\end{tabular}

in Magnesium after treatment (data not shown). Additionally, the result of treated AMD water indicates that fly ash is capable of bringing the $\mathrm{pH}$ of AMD water to an accepted $\mathrm{pH}(6.5$ - 8.5) for natural waters as shown in Table 3 [9].

\section{Conclusion}

We conclude that the fly ash has the ability of complete removal of the iron and reduce acidity of coal mine drainage water. Similarly, this method can be tested for other contaminants such as magnesium.

\section{Acknowledgements}

We would like to thank Dr. Bergmeier, Chair of Chemistry Department at Ohio University for his generous financial support. 


\section{References}

[1] Michelle, S. (2012) College Green Magazine. History of Coal Mining Leaves Scarred Land, Polluted Waters in Southeast Ohio.

http://www.collegegreenmag.com/history-of-coal-mining-leaves-scarred-land-polluted-wat ers-in-southeast-ohio

[2] Appalachian Regional Commission (1973) The Economic Impact of Public Policy in the Appalachia Coal Industry and the Regional Economy. Charles River Associates, Inc. Technical Report (511 pages).

[3] OHIO DEPARTMENT OF NATURAL RESOURCES. http://www.ohiodnr.com/mineral/acid/tabid/10421/Default.aspx

[4] Sobek, A.A., Schuller, W.A., Freeman, J.R. and Smith, R.M. (1978) Field and Laboratory Methods Applicable to Overburdens and Minesoils. EPA600/2-78-054, PB-280495.

[5] Butalia, T.S. and William, E.W. (2003) Coal Combustion Products Extension Program. http://www.osti.gov/scitech/servlets/purl/892565

[6] https://www.fhwa.dot.gov/pavement/recycling/fach07.cfm

[7] Ghaffari, S. and Lambes, B. (2006) Using Fly Ash for Removal of Hazardous Substances from Water. American Journal of Undergraduate Research, 4, 7-9.

[8] Harris, D.C. (2010) Exploring Chemical Analysis. 5th Edition, W. H. Freeman Co.

[9] Department of Ecology, A Citizen's Guide to Understanding and Monitoring Lakes and Streams.

http://www.ecy.wa.gov/programs/wq/plants/management/joysmanual/streamph.html

Submit or recommend next manuscript to SCIRP and we will provide best service for you:

Accepting pre-submission inquiries through Email, Facebook, LinkedIn, Twitter, etc.

A wide selection of journals (inclusive of 9 subjects, more than 200 journals)

Providing 24-hour high-quality service

User-friendly online submission system

Fair and swift peer-review system

Efficient typesetting and proofreading procedure

Display of the result of downloads and visits, as well as the number of cited articles

Maximum dissemination of your research work

Submit your manuscript at: http://papersubmission.scirp.org/ 